\title{
6. \\ DALMATINSKI MEDITERANIZAM \\ VLADANA DESNICE: SPLITSKI PERIOD
}

\section{Svetlana Šeatović Dimitrijević}

UDK: 821.163.42Desnica, V.:304(497.58)

Izvorni znanstveni članak

Sažetak: U radu se analiziraju uticaji Splita kao oblika književne topografije, ali i šireg prostora Dalmacije i Mediterana u romanu Proljeće Ivana Galeba. S obzirom da je jedan deo ovog romana nastao baš u Splitu, ispituju se uticaji i odjeci ovog grada u imaginativnom aspektu Desničinog dela. Analiza prati antropogeografske karakteristike Dalmacije i tipične motive Sunca, svetlosti, mora i autentičnih socijalnih pojava vezanih za prostor u kome je započeto pisanje Proljeće Ivana Galeba. Period života Vladana Desnice u Splitu dovodi se i u vezu sa njegovim uređivanjem Magazina Sjeverne Dalmacije (1934. i 1935. godine) nekoliko pesničkih tekstova tipičnog dalmatinskog ambijenta i eseja posvećenih Dositeju i Mirku Koroliji. Roman Proljeće Ivana Galeba se stavlja i u širi komparativni kontekst prema poeziji i esejima Pola Valerija, esejima Albera Kamija, ali i piscima savremenicima Ivi Andriću, Dušanu Matiću, Ivanu V. Laliću i Jovanu Hristiću kao književnicima koji su razvili filozofiju mediteranofilije u svojim opusima u drugoj polovini 20. veka sa elementima epifanijskih doživljaja. Dalmatinski mediteranizam prožima celokupno Desničino delo, ali je ovaj rad usmeren samo na period proveden u Splitu (1920-1945). U radu se analiziraju dovršeni pesnički, esejistički radovi i započeti delovi romana Proljeće Ivana Galeba. Tema Desničinog mediteranizma zahteva mnogo veći istraživački posao koji bi uključio ceo pesnički i pripovedački rad i prevazilazi domete jedne studije. ${ }^{1}$

Ključne reči: Mediteran, Dalmacija, antropogeografija, pejzaž, biografija, imaginacija, more, Sunce

Dalmacija i Mediteran i mediteransko podneblje su jako mnogo uticali na mene. O tome nema govora. I čitav bih ja bio sasvim drukčiji da nisam na tom podrucjju odrastao i tu roden.

Vladan Desnica, iz intervjua Jevtu M. Miloviću 1964. godine

Rad je nastao u okviru naučnog projekta „Smena poetičkih paradigmi u srpskoj književnosti: nacionalni i evropski kontekst" br. 178016 Ministarstva prosvete, nauke i tehnološkog razvoja Republike Srbije u Institutu za književnost i umetnost, Beograd. 
U intervjuu Jevtu M. Miloviću 1964. godine u Zadru Vladan Desnica odgovara veoma opširno o životu, književnom opusu, odnosu autobiografskog i fiktivnog, a pri kraju intervjua zamera kritičarima što, iako su mnogo pisali o Proljeću Ivana Galeba, ipak nisu videli ovaj roman kao knjigu Dalmacije i Mediterana, „osim nešto malo Rismondo“.2 Mnogo kritika je pisano, ali Desnica tada primećuje da je kritičarima izmakla i analiza ritma i kompozicije ovog romana. Osnovna ideja o temi ovog teksta nastala je i pre čitanja Desničinog intervjua tako da nam se tek sada naša tema čini još važnijom i nekom vrstom duga jer je i sam pisac ovaj roman doživljavao kao knjigu Dalmacije i Mediterana. Prostor, književna topografija, odnos biografskog i imaginativnog, i sve to u estetskom okviru, predstavljaju osnovni model od koga ćemo proći kroz splitske dane Proljeća Ivana Galeba. Mada je ovaj roman Desnica započeo krajem tridesetih godina u Splitu, a potom ga dovršavao još 25 godina u različitim mestima, Split je bio polazna stanica i izvor. Docnije je izjavio da su početkom rata 1941. Proljeća Ivana Galeba bila: „(...) jedna duža pripovijest koja je sadržavala samo djetinjstvo: ona poglavlja iz djetinjstva su bila otprilike gotova već prije rata. Ne u ovoj formi. To sam se poslije po deset puta navraćao i dotjerivao.“3 $\mathrm{Nema}$ sumnje da dvadeset godina života u Splitu, poznavanje ovoga grada, njegovih ljudi, kao i šireg prostora Dalmacije do rodnog Zadra i Islama Grčkog predstavljaju bazičnu tačku na kojoj je započeo umetnički rad Vladana Desnice, pisca i vrhunskog intelektualca. Zbog toga je i centralna tačka Desničinog opusa Dalmacija i Split. Pokušali smo da odredimo tu regionalnu i estetsku specifičnost. Imenovali smo je kao dalmatinski mediteranizam. Desnica je prilikom napada na roman Zimsko ljetovanje pružio sistematičan odgovor koji objašnjava odnos pisca i sredine u kojoj je stvarao:

Čovjek može da umjetnički uspješno savlada temu situacije samo onda ako su mu sredina, prilike, ljudi, mentaliteti, odnosi, atmosfera, pa čak i pejzaži, i štimunzi, i osvjetljenja, mirisi, zvukovi, prisno i od davnina poznati, ako mu je podsvijest uprav natopljena svom tom sadržinom, ako iz te sredine i iz tog životnog sklopa u sebi nosi prebogate naslage iskustva i saznanja, ako sigurno pozna i nepogrešivo osjeća svaku i najmanju pojedinost, svaki najtananiji psihički pokret, svaku intonaciju glasa; ako u sebi nosi čitavu galeriju tipova, ako ima već gotovo i nedvojbeno točnu intuiciju svakog lica i svake njegove reakcije u bilo kojoj datoj situaciji. ${ }^{4}$

Desnica je ovim odgovorom jasno definisao opravdanost metodološkog pristupa njegovim delima iz pozicije Dalmacije, rodne sredine i mentaliteta ljudi.

Šta je to dalmatinski mediteranizam? Kako se on ugrađuje u književni opus Vladana Desnice, jednog od najautentičnijih pisaca slovenskog juga? Da li samo kao rodni prostor ili kao deo jedne šire regionalne antropologije i filozofije mediteranofila? Pre svih, tu su filozofije Benedeta Kročea, koga je i prevodio, poezije Đakoma Leopardija, Gabrijela D’Anuncija, rođenog u Peskari, tačno nasuprot Splita samo sa druge, italijanske strane Ja-

2 Jevto M. Milović, „Razgovor s Vladanom Desnicom o umjetničkom stvaranju“, u: Vladan Desnica, Eseji, kritike, pogledi (= Sabrana djela Vladana Desnice, knj. IV), Zagreb 1975., 235.

3 Isto, 229.

4 Vladan Desnica, „O jednom gradu i jednoj knjizi“, Eseji, kritike, pogledi, 102-103. Navedeni tekst je odgovor Joži Horvatu povodom kritike romana Zimsko ljetovanje i objavljen je 1954. godine u časopisu Zadarska revija. 
drana, a potom i opusa Pola Valerija. Desničini splitski dani na koje se usmeravamo nisu samo godine u kojima je započeo pisanje romana Proljeća Ivana Galeba, kako je i sam pisac svedočio na više mesta, već su i godine intelektualnog i profesionalnog sazrevanja. Mada će taj roman, po piščevim rečima doživeti mnoge izmene, sasvim je jasno da su pojedini delovi Splita - kuće, ulice, običaji i stil komunikacije - deo Desničinih splitskih dana. Širina pogleda i istančana psihologizacija junaka u ambijentima dalmatinskih gradova i zaleđa donose specifičnu atmosferu koja je vezana za prostor, ali otvaraju i čitav niz mogućnosti za razumevanje čoveka i njegovih unutrašnjih nemira. Jovan Dučić je jednom prilikom Ivi Andriću kazao: „Okanite se već jednom Bosne, siđite na more - to je svet“. 5 Napokon, i sam Andrić je priznao da je Dučić „prolio“ more ispred njegovih očiju. ${ }^{6}$ Blizina mora, uvale i mediteranski stil života sa prebogatim nasleđem civilizacija, od antičke do savremenih, predstavljaju taj specifični podsticajni ugao iz koga se svet posmatra očima beskraja. Desničini junaci će nositi te dubine i autorefleksije u blizini mora, igrama proleća i smrti. Nije dakle reč samo o pejzažnim elementima kao dekoru Desničinih junaka već i o mikrokosmosu tih ljudi obeleženih regionalnim karakteristikama - jezikom i kulturom kao specifičnim osobinama dalmatinskog podneblja. Ako se uzme u obzir i istorijski složena pozicija Dalmacije u odnosu na Mletačku republiku, pa potom i savremenu Italiju, a sa druge strane mešavinu naroda i religija, sasvim je logično da su i junaci Vladana Desnice kao veoma pronicljivog pisca bili deo te složene kulturološko-antropološke istorijske paradigme. U Magazinu Sjeverne Dalmacije, koji je Desnica uređivao i objavljivao u Splitu 1934. i 1935. godine, ovaj pisac će publikovati i dva izuzetna književnoistorijska eseja: jedan o Dositeju, drugi o Mirku Koroliji i njegovom kraju. Pored toga tu su tri pesme sa jasnim asocijacijama na dalmatinski pejzažni okvir i socijalnu sliku sveta.

U pesmama „Seljani“ i „Djevojke na vodi“ sa nadnaslovom „Dvije impresije iz Sjeverne Dalmacije" Desnica u najranijem književnom periodu, koji počinje u Splitu i koji publikuje u Magazinu Sjeverne Dalmacije 1934. godine, pokazuje apsolutnu privrženost rodnom prostoru, a u navedenim pesmama oživljava atmosferu pejzaža Dalmacije i seoskog stanovništva. U pesmi „Seljani“ Desnica prenosi doživljaj tople letnje noći u kojoj putem prolaze seljačka kola sa pijanim seljanima koji se vraćaju sa sajma. Pejzaž letnje noći samo je okvir. Vidimo da Desnica u svojim prvim pesmama teži predstavljanju narodnih masa, njihovog mentaliteta, pa time pokazuje duboku saživljenost sa krajem iz koga i sam potiče i narodom koji je bio i radna osnova bogatog porodičnog imanja u Islamu Grčkom. Umesto otmenosti bogatih veleposednika Desnica se u ovim pesmama usmerava na pejzažne i socijalne motive koji su dominantni u Severnoj Dalmaciji. U pesmi „Djevojke na vodi“ Desnica nam donosi likove žena koje nose vodu - opet u toplom periodu godine kada se svet svodi na praelement vode kao suštinske potrebe - i ruralnu atmosferu u kojoj te žene sa primesama fine erotike postaju životvorni element pejzaža. Možemo samo pretpostaviti da je Desnica ovu pesmu napisao u Islamu Grčkom ili u Splitu, ali svakako prema sećanjima na događaje iz Islama:

5 Ljubo JANDRIć, Sa Ivom Andrićem, Beograd 1977., 365.

6 Isto. 
Il nešto kao da viču...

- al jugo im kosu mrsi

I riječi iz upalih prsi

u vjetru kroz polja lete

i razdrte se viju

ko mokre krpe...

$\mathrm{O}$, što to u vjetar siju:

Da l' zovu, kunu il' prijete?'

U pesmi „Ljetni motiv“ Desnica oživljava pejzažnu atmosferu leta u vreme zrelog žita, pa tako iz konteksta opet imamo julske dane, period vegetativnog zenita kada se ruralni čovek sprema da ubere prvu letinu i skine s polja suvo žito, glavni izvor hrane. Za Desnicu je ovo leto u zaleđu mora, najverovatnije opet impresija iz Islama Grčkog gde „suha žita lagano zašušte/dremežnu pjesmu ljeta koje sniva“. ${ }^{8}$ Tako se pred čitaocima otvara svet Desničinog zrelog leta, mediteranskog podneblja, igre svetlosti i senki, blizine smrti u trenucima najvišeg životnog i prirodnog zenita, a to će razviti u pesmi „Začarano podne“ u zbirci Slijepac na žalu. Pesma „Začarano podne“ priziva atmosferu mistike podneva u zaleđu mora, prenosi zvukove iz prirode, zamukle glasove crvčaka i tišinu „srpanjskog dana“:

Umuko je cvrčak. Ne njišse se grana

majčinski nad glavom. Na polja je legla

ustreptala jara srpanjskog dana.?

Tako se već u prvoj strofi ove pesme potvrđuju epifanijski ${ }^{10}$ trenuci mističnog podneva koje ćemo naći u srpskoj i hrvatskoj književnosti posle 1945. godine kao pejzažne pesme, ali i kao odraze metafizike takvih podneva u kojima se spoznaju istine o bivstvu sveta. Takve pesme nalazimo kod Vladimira Nazora, ali i Ivana V. Lalića i Jovana Hristića. S druge strane, pre 1918. godine Jovan Dučić će u pesmi „Podne“ oživljavati mediteransku atmosferu žarkog podneva, pejzažne trenutke topline, jasnosti sveta i Sunca u zenitu sa detaljima flore i faune hercegovačkog krša ili obalskog dela Dubrovnika:

Nad ostrvom punim čempresa i bora,

Mlado, krupno sunce prži, puno plama;

I trepti nad šumom i nad obalama

Slan i modar miris proletnjega mora.

(...)

Nemo stoje u njoj srebrnaste, rodne

Obale i vrti; i svetli i pali

Mlado, krupno sunce; i ne šušte vali, -

Galeb još svetluca. Mir. Svuda je podne. ${ }^{11}$

\footnotetext{
Vladan Desnica, „Ljetni motiv“, Magazin Sjeverne Dalmacije, 1/1934., 89.

8 Isto.

9 Vladan Desnica, „Začarano podne“, Slijepac na žalu, 9.

10 Vlatko Pavletić u knjizi Trenutak vječnosti. Uvodenje u poetiku epifanija tumači epifanijske trenutke: „Epifanija nas najneposrednije suočava sa životom kao postojanjem, koje svoj smisao ne duguje ničemu izvan sebe, nikakvom apsolutu; jer epifanijski sagledan život je postojanje, a postojanje je Apsolut." Vlatko PAVletić, Trenutak vječnosti. Uvodenje u poetiku epifanija, Zagreb 2008., 11.

11 Jovan Dučić, „Podne“, Pesme (= Dela Jovana Dučića, sv. 1, prir. Rajko Petrov Nogo), Beograd - Podgorica - Trebinje 2000., 30 .
} 
Mistika podneva i kroz poeziju južnoslovenskih prostora od početka 20. veka ima posebno mesto i predstavlja jedan tematski spektar koji je inspirisao pesnike rođene Mediterance ili one koji su odrasli u mediteranskom zaleđu. Vlatko Pavletić je o ovoj Dučićevoj pesmi primetio: „(...) jer se u njoj ne pjeva o podnevu kao razdoblju dana, nego o jednoj neponovljivoj ljepoti življenja i stanju duše pjesnikove - sve to sugerirano, simbolizirano ozračjem ljetnog podneva!"12

Tako se Desničine pesme objavljene u Magazinu Sjeverne Dalmacije mogu sagledati u širem književnoistorijskom i poetičkom kontekstu. Podnevni muk je oksimoronska rečita tišina, onaj epifanijski trenutak na ivici vidljivog i nevidljivog i najava izuzetno definisanih oksimorona zasnovanih na mediternskom pejzažu, kao što će to biti i naslov Zimsko ljetovanje. Određeni trenuci u Desničinim ranim pesmama i prvim poglavljima Proljeća Ivana Galeba predstavljaju prave primere epifanija tj. višestrukih doživljaja sasvim običnih životnih pojava. Poseban značaj tim trenucima daju svetlost i toplina kao osnovni pejzažni elementi Dalmacije i celog Mediterana. Time se i u najranijoj splitskoj fazi Desnica približava epifanijama u delu Pola Valerija, Marsela Prusta i nadrealista. Delovanje jednog detalja iz detinjstva ili iz trenutnog opažanja odvodi Desničinog junaka ili lirsko ja u asocijativni svet prošlosti ili trenutaka savršenog spoznanja najviših istina. U vreme kada Desnica piše u Splitu on i prevodi Leopardija, a Vlatko Pavletić u studiji o epifanji upravo ukazuje na prve oblike epifanije kod Leopardija u pesmi „Uspomeni na prvu ljubav“. ${ }^{13}$ Tako pogledom na samo nekoliko pesama iz splitskog perioda, prevođenje i uređivanje Magazina Sjeverne Dalmacije nalazimo prve odlike dalmatinskog mediteranizma u opusu Vladana Desnice.

Esej o Mirku Koroliji u uvodnom delu donosi sažetu i nadahnutu sudbinu Dalmacije i ljudi tog regiona. S obzirom da je reč o eseju objavljenom u drugom broju Magazina Sjeverne Dalmacije 1935. godine, koji pokazuje istorijsko, geografsko, klimatsko, socijalno i antropološko stanje ljudi dalmatinskog kraja, a da to korespondira sa prvim počecima pisanja romana Proljeća Ivana Galeba u Splitu, sasvim sigurno možemo da tvrdimo da je proces samospoznanja umetničkih ideja oslonjenih na Dalmaciju i stanovništvo tog kraja sazrevao u Desničinoj svesti, a potom je i pretočen u izvrsno napisan esej u periodu života u Splitu. Magazin Sjeverne Dalmacije u tom splitskom periodu pored istorijskih, političkih, kulturnih, gospodarstvenih prilika o kojima pišu Uroš i Boško Desnica i drugi saradnici pokazuje i širu sliku sveta Dalmacije, ali je tekst Vladana Desnice o Koroliji jedan od najpreciznijih jer oslikava bogatstvo i šarolikost ovog prostora:

Dalmacija u svojoj cjelini obuhvata i sjedinjuje razna područja koja se, pod djelovanjem posebnih prirodnih uslova i različitih istorijskih udesa, među sobom dosta oštro razlikuju. U toj zemlji gdje raste oleandar i grab; gdje uz obalu u maistralu leprša dašak romanskog duha i vije laka zapadna melopeja, a po zaleđu u buri struji duboko rasni narodni život i grubi primitivni monokord; gdje uz katedrale sa Ticijanima i Veronezima postoje i manastiri u kojima tinja duh srednjevjekovne srpske manastirske obrazovanosti, u kojima caruju krute bizantinske ikone i u kojima se čuvaju zavjeti Nemanjića; gdje pored primorskog trubadura nalazimo i mrgodnog brđanskog kaluđera ljetopisca - u toj zemlji, među raznovrsnim

12 V. Pavletić, Trenutak vječnosti, 213.

13 Videti opširnije: Isto, 93-94. 
osobitostima koje je uslovila priroda i stvorila istorija, i sjevernodalmatinski kopneni kraj, naseljen izbjeglicama koji su se od 15. vijeka dalje sklanjali pred Turcima na njegov goli krš i sure visoravni, predstavlja, po svojim specijalnim kulturnim, psihičkim i ekonomskim momentima, jedno izdvojeno područje. ${ }^{14}$

Desnica suštinski razume sve različitosti dalmatinskog podneblja, klimatske, geografske, istorijske i verske mešavine. To je i po definiciji tipična mediterska slika, kako kaže Brodel: „To je taj šareni Mediteran." 15 S druge strane, Jovan Cvijić je u studiji Antropogeografski problemi Balkanskog poluostrva (1902) dao osnove za razumevanje odnosa čoveka i sredine, etnološke i etnopsihološke karakteristike koje će biti definisane u delu Balkansko poluostrvo i južnoslovenske zemlje. ${ }^{16}$ Cvijić će u odeljku „Jadranski varijetet“ kazati:

Ovo se južnoslovensko stanovništvo izmenilo pod uticajem mora i mediteranske klime: jedino su se među Slovenima neke grupe iz ovih krajeva prilagodile mediteranskom načinu života, tako da daju čuvene mornare. Takođe su jedino oni među Južnim Slovenima iskoristili veze $s$ morem i došli u dodir sa prekomorskim narodima i sa raznim civilizacijama. Primorske su grupe živele u sredini jako prožetoj romanskom civilizacijom; još i sada ima kod njih nekih tragova vizantijske civilizacije naročito iz 7. do 10. veka, kao i nekih jedva vidnih ostataka istočnjačke civilizacije. ${ }^{17}$

Cvijić ističe da se u jadranskom varijetetu, koji je bio pod mnogobrojnim uticajima, upravo pojavljuju drugačije osobine nego kod dinarskih varijeteta, zaključujući da je upravo jadranski varijetet sa svim mešavinama jedna od najsnažnijih i najaktivnijih grupa među zapadnim Južnim Slovenima. Tako kroz dela antropogeografije i Desničina tačna definisanja mentaliteta sredinom tridesetih godina nalazimo jasnu svest ovog pisca o osobenostima dalmatinskog koje je istovremeno mediteransko podneblje sa svim karakteristikama šarenila Mediterana. Fernan Brodel granice Mediterana tumači kao susrete kultura i ivice, obode Sredozemlja koji predstavljaju prave ožiljke:

Ali, najčudniji ožiljak sredozemnih zemalja stoji između Istoka i Zapada, preko morskih barijera (...), ona nepromjenjiva barijera koja prolazi između Zagreba i Beograda, izbija kod Lješa na Jadran, na ušće Drima i na mjesto dodira dalmatinskih i albanskih obala, pa preko starih gradova Naissusa, Remesine i Ratiare izlazi na Dunav. Sav dinarski blok je bio latinizovan, počev od Panonske nizije uhvaćene zapadnim dijelom Carstva i na koji izlaze široke doline $s$ gorja, do rese morske obale i ostrvlja prema Italiji. ${ }^{18}$

Dalmatinski mediteranizam kod Vladana Desnice funkcioniše kao literarno nasleđe, ali i kao deo prirodnog i urbanog pejzaža. Desnica objašnjava prirodu zaleđa Dalmacije posle 1945. godine zbog polemike koju je vodio povodom Zimskog ljetovanja, ali jasno naglašava kako je Dalmaciji dano more kao blagodet, dok u zaleđu ostaje kršs, neprosvećenost, tvrd i sirov pejzaž koji ne razvija osećanja. Zaleđe je za Desnicu poslednja oaza partijarhalizma i

\footnotetext{
14 Vladan Desnica, „Mirko Korolija i njegov kraj“, Magazin Sjeverne Dalmacije, 2/1935., 25.

15 Fernan Brodel, Mediteran i mediteranski svet u doba Filipa II, sv. 2, Beograd 2001., 55.

16 Delo je tiskano u Parizu 1918. godine, a potom u Beogradu 1922. i posthumno 1931.

17 Jovan Cvijıć, Psihičke osobine Južnih Slovena, Beograd 2006., 118-119.

18 F. Brodel, Mediteran i mediteranski svet u doba Filipa II, sv. 2, 112.
} 
epskog duha, pa ovako istančanu diferencijaciju može izvesti samo dobar poznavalac i onaj čiji je to rodni prostor. Cvijić je takođe isticao zaostalost zaleđa i širinu i otvorenost ljudi u primorskim gradovima: „(...) kao svekoliko evropsko mediteransko stanovništvo, tako [se] i ovo primorsko, naročito sa dalmatinskog primorja, odlikuje živahnošću i gipkošću. Manje je nego drugi narodi balkanskih prostora zahvaćeno fatalističkom rezignacijom. " ${ }^{19}$ Tako bismo kroz Magazin Sjeverne Dalmacije, Desničine pronicljive tekstove, Brodelove i Cvijićeve zaključke mogli ukratko definisati dalmatinski mediteranizam, regionalan i makroregionalan u isti mah, sa specifičnostima njegovog zaleđa. Ipak, dvadeset godina života u Splitu Desnici su dali taj ključni intelektualni vetar u leđa uz odlaske na školovanje u Pariz i Zagreb. U pozadini sudbina njegovih kasnijih junaka u Olupinama na suncu promiču odjeci oslobođenja delova Dalmacije, uticaja Austrougarske, ali i sudbine interniraca u Prvom svetskom ratu, što bi mogao da bude i odjek porodične istorije i sudbine njegovog oca Uroša, interniranog u Italiju. Potom slede istorijske konotacije ujedinjenja 1918. godine, ali i nestabilnosti pojedinaca u tokovima istorijskih i društvenih promena. $\mathrm{Na}$ taj način se Desnica približava Tomasu Manu ili Marselu Prustu, skicirajući sudbine pojedinca u istorijskim procesima, a da su pri tome ti događaji samo asocijativno napomenuti jer se fokus problema nalazi u unutrašnjim tokovima junaka.

Splitski period u kome se formira Desničin dalmatinski mediteranizam je pored aktivnosti u uređivanju časopisa Magazina Sjeverne Dalmacije i objavljivanja esejističkih i pesničkih tekstova veoma važan i zbog rada na romanu Proljeća Ivana Galeba. Veoma blizak prijatelj Vladana Desnice u tom periodu je Vladimir Rismondo, sa kojim će druženje ostati celoživotno, pa su Rismondova zapažanja i ocene književnog rada odlična polazna tačka za svakog tumača. Rismondo je jedini isticao mediteransku, regionalnu, ali i antičku misao sredozemnog prostora u kome se formirao Desnica. Poseban uticaj u definisanju Desničinog mediteranizma ima i njegovo poznavanje italijanske književnosti, prevodi Leopardija, a posebno prevod Kročeove estetike, objavljene pod naslovom Eseji iz estetike. Štampana je u splitskoj izdavačkoj kući „Kadmos“ 1938. godine. Uticaj italijanske književnosti do sada su već tumačili i dokazali Sanja Roić i Željko Đurić. U pesmi „Pred kišu“ Đurić nalazi direktan uticaj D’Anuncijeve pesme „La pioggia nel pineto“, kao i „galaktičke sanjarije“ iz Leopardijeve pesme „Ginestra“ u romanu Proljeća Ivana Galeba. ${ }^{20}$ Đurić nalazi direktne uticaje Kročeove estetike na Desničin opus, ali isto tako i pokazuje koliko je ovaj pisac bio osoben i svoj. S druge strane, Đurić ukazuje i na uticaje Paskolija i D’Anuncija kao pesnika „krepuskolara“ čiju estetiku i tematski okvir Desnica transponuje u poeziju, ali i u Proljeća Ivana Galeba ${ }^{21}$ Ovi uticaji italijanske književnosti i estetike samo potvrđuju mediterani-

19 J. Cvijıć, Psihičke osobine Južnih Slovena, 142.

20 Videti opširnije: Željko Đurić, „Vladan Desnica i italijanska književnost“, Književno delo Vladana Desnice (ur. Jovan Radulović i Dušan Ivanić), Beograd 2007., 162-174.

21 Đurić uticaje Paskolija i D’Anuncija navodi u nizu estetičkih i tematskih obeležja nazivajući ih krepuskolarima, kako ih i definiše italijanska književnost: „Krepuskolari, tako, pokazuju: - jasan dekadentan stav prema životu; - težnju povlačenja u sebe, bitisanje u stanju umorne melanholije, u uzaludnoj žudnji za onim što ne mogu postići, u nostalgično-ironičnom žalu za onim što je prošlo; - 'osećati sopstveno umiranje' - to je tajna patnja koja izjeda te pesnike u njihovom očajanom prepuštanju; pošto ne umeju da pronađu razlog za život, oni utočište pred tugom traže u utešiteljskom snevanju jednostavnog postojanja; - njihove omiljene i česte teme i simboli njihove poezije - skrovišta 
zam Desničinog dela. Opus Vladana Desnice, posebno onaj koji je započet u splitskom periodu, možemo posmatrati kao oblik kulturnog obrasca mediteranizma u korpusu naše književnosti, ali i šire regionalne i kulturološke zajednice mediteranskih naroda kojima ovaj pisac pripada rođenjem i obrazovanjem. Kasnije Desničine pripovetke „Bog sve vidi“, „Posjeta“, „Solilokvij gospodina Pinka“, zbirka Olupine na suncu, kao i Proljeća Ivana Galeba sukobljavaju dve osnovne teme života i smrti, kao što to metaforički kazuju i igre proljeća i smrti u autentičnom mediteranskom ambijentu komparativno prizivajući celu plejadu mediteranskih pisaca, a pre svega Pola Valerija i njegove ideje iznete u knjizi Mediteranska nadahnuća. Mada između Desnice i Valerija postoji razlika u žanrovskom određenju, misao o životu i smrti na antičkim filozofskim osnovama se nalazi kao zajednički imenitelj. Sudari lokalnog i opšteg, kao i šireg regionalnog prostora prelomljeni kroz životnu putanju Vladana Desnice i specifičnosti kulturnog i društvenog miljea metodološki doprinose dalmatinskom mediteranizmu ovog pisca. Odnos geografskog, životnog i poetičkog kod Desnice se ukrštaju već od prvih pesama u Magazinu Sjeverne Dalmacije, eseja o Koroliji, a potom razvijaju u Proljećima Ivana Galeba.

Vladimir Rismondo, prijatelj i kritičar Vladana Desnice opisuje piščev postupak u kome se spoljašnji detalji prelivaju u unutrašnja stanja junaka i lirskog subjekta:

Iza svake teme, iza svakog unutrašnjeg pokreta, iza najnasmijanijeg vanjskog privida, kao da odjekuje onaj njegov, iskonski praočaj bivstvovanja. A u tome leži najintimnija značajka i najveća sugestivnost kako Desničine poezije stiha tako i Desničine poezije proze. ${ }^{22}$

Rismondo napominje da je Desnica određen svojim „mediteranskim odgojem“ $i$,mediteranskom naravi“ pa tako i u iskazima najbližeg dugogodišnjeg prijatelja u Splitu i Zadru možemo naći potvrdu za naše stavove o neizbežnosti određenja Desničinog opusa kao izrazito dalmatinskog i mediteranskog u pogledu porekla, antropologije i estetsko kulturološkog pristupa književnosti. U Desničinom opusu mogli bismo primeniti značaj životne biografije i geografije, rodnih prostora Zadra, Splita i Islama Grčkog. ${ }^{23} \mathrm{~S}$ obzirom na dominaciju elemenata gradskog, urbanog pejzaža i njegove metafizike u sudbini glavnog junaka neophodni su pogledi u Split i Dalmaciju. Rismondo veoma lucidno primećuje korelaciju Desničinih dela i samog autora:

(...) psiha Vladana Desnice, kako sam je ja osjetio i pokušao da definiram, u svom intimnom tkivu je mediteranska, jer je ona srodna psihi antičkih grčkih ljudi, kako se ona u najvišim dostignućima njihovih duhova manifestirala. Zato se Vladan Desnica može na-

stare kuće, stare četvrti, bezbojan i dremljivi život provincije, zvuk kućnih instrumenata, hodnici bolnica, napušteni vrtovi, beskrajni zamor nedeljnih popodneva, lagana muzika." Isto, 173-174.

22 Vladimir Rismondo, „Poezija Vladana Desnice“, Oblici i slova, Split 1979., 134.

23 Opširnu biografiju ratnog perioda Vladana Desnice i njegove porodice detaljno je tumačio Drago Roksandić, „Ratni dani Vladana Desnice", Intelektualci i rat 1939. - 1947. Zbornik radova s medunarodnog skupa Desničini susreti 2012. (ur. Drago Roksandić i Ivana Cvijović Javorina), sv. 2, Zagreb 2013., 529-553. U istom radu Roksandić na osnovu dokumenata objašnjava i ulogu Vladimira Rismonda u Desničinom životu: „Vladimir Rismondo bio je Vladanu Desnici od mladosti do svoje smrti vjerojatno jedan od najbližih ljudi izvan obiteljskog kruga. Izgleda da su neko vrijeme bili zajedno u Zadru 1942. godine. Za nikoga se Vladan Desnica u svojim ratnim pismima u Split nije toliko raspitivao kao za njega, njega je prvog zvao da dođe iz gladnog Splita u koliko-toliko nahranjeni Islam Grčki itd. Bliski su ostali i poslije 1945. godine." Isto, 550. 
zvati mediteranskim piscem i, prema tome, i zadarskim i dalmatinskim. Samo u jednom dubljem i posebnijem značenju ovih posljednjih riječi. ${ }^{24}$

Vladimir Rismondo daje jednu od najpreciznijih odrednica Desničinog književnog dela, koja nije samo pitanje porekla, kulture, već ukazuje na taj put transformacije koji nas vodi takođe i u samo središte estetskog u njegovom delu. Sinteza čoveka i pejzaža sa osobinama kulture predstavlja jednu od glavnih formula Desničinog književnog dela. Rismondo diferencira uticaje Islama Grčkog kao zaleđa mora i iskustvo života u gradovima uz more, Zadru i Splitu zaključujući da je kod Desnice otkrio

(...) intimnu povezanost, koju je Vladan Desnica uspio da pronađe između ovih dvaju svjetova i osjetio sam da je on na terenu Grčkog Islama i Bukovice jednako svoj i čitav kao u svojim skroz intimnim stihovima iz prve mladosti i u, mnogo kasnijim, Proljećima Ivana Galeba. ${ }^{25}$

Zbog toga se kod posmatranja splitskih dana Vladana Desnice ne treba zaboraviti uticaj sećanja na zaleđe i likove koji će doći sa planine u Galebovu kuću, ruralne junake, kao što su npr. dojilja i njen muž.

\section{Proljeća Ivana Galeba. Igre proljeća i smrti}

Već na prvoj stranici romana Ivan Galeb, junak tipično simboličnog imena mediteranskog okruženja, vidi kalendar sa natpisom „Sretna nova 1936. godina!“ Kako je i sam Desnica svedočio, ovaj roman je te godine i nastajao baš u Splitu, pa tako iz detalja romana, izjava pisca i saznanja o splitskim danima jasno možemo da rekonstruišemo period nastanka i mesto življenja našeg junaka i pisca. Detalji dalmatinskih letnjih dana se nižu i dalje: igre svetlosti i senki iza zatvorenih škura Galeb vidi svet kao izvrnutu sliku:

(...) tako sam se zabavljao i nekad davno, davno. U sobu mog djetinjstva isto je tako prodirala izvrnuta slika svijeta napolju, u ljetna popodneva kad sam poslije kupanja ležao s još vlažnom kosom na uzglavlju koje je mirisalo po suncu. Lickao sam bjelkastu sočicu što se uhvatila po mojim izduljenim udovima i motrio to malo strmoglavljeno ljudstvo koje mi je došlo u pohode. Samo je onda slika bila blago uznemirena, sva oživljena neumornim šaranjem zmijastih pruga od refleksa mora koje je ravnomjerno disalo pod prozorima u luci. ${ }^{26}$

Već u procesu sećanja junaka vratiće se sada dalmatinska, mediteranska kamena kuća, ali sa dva kata. Po opisu to nije kuća u kojoj je živeo Desnica, ali u njegovim sećanjima on objašnjava o kojoj je splitskoj kući reč. U razgovoru sa Jevtom Milovićem 1964. godine Desnica objašnjava poreklo kuće koja se našla u romanu:

\footnotetext{
24 Vladimir Rismondo, „Književni profil Vladana Desnice“, Oblici i slova, Split 1979., 183.

25 Vladimir Rismondo „Sjećanja na Vladana Desnicu“, Oblici i slova, Split 1979., 219-220.

26 Vladan Desnica, Proljeća Ivana Galeba, Zagreb 1982., 8.
} 
Ta je kuća, to nije moja kuća niti kuća u kojoj sam ljetovao, to je jedna kuća u Splitu. Otalen se svjesno sjećam jer sam na više mjesta živio, imao dodira s tim kuglama, ali svjesno se sjećam najbolje jedne kuće u Splitu na obali. Stara jedna kuća gdje sam nekom prijatelju išao. Postojao je jedan takav hodnik sa kvakama. Sve se miješa, a bezbroj detalja. ${ }^{27}$

Desnica napominje da se upravo svi detalji iz njegovog stvarnog života mešaju jer je roman pisao dvadeset pet godina i prirodno je da se unose različiti prostori, ali svi su oni suštinski na obali ili zaleđu Dalmacije. Autobiografski element je nemoguće poricati, pa je tako u intervjuu sa Milovićem kazao i sledeće: „A kuća, znate, u mnogim sam kućama živio, i gradskim, i na selu, na imanju, i u raznim gradovima, pa se sve to miješa, osobito ono iz djetinjstva. Pojedini detalj se uzme odavde i odande. Pejzaža mnogo ima iz Islama. Pejzaža i štimunga u mojim djelima. “28 Dakle, pred nama je tipična arhitektura, materijali kamena, a onda se u opisu te kuće, podeljene na levu i desnu stranu, dolazi do diferencijacije delova kuće okrenutih ka moru i nasuprot njemu. More kao praelement, igre svetlosti i senki u hodniku u kome se delila kuća na sunčanu i senovitu stranu tako se estetski uobličavaju u dve strane ljudskog bića, svetlu i tamnu, igru proleća i smrti, igru života i smrti, erosa i tanatosa. Zbog toga dalmatinski pejzažni okvir u kome se odmah iza kuće diže „krševita strmina“ ukazuje kako se od realističkog opisa duboko utkanog - kako reče i sam Desnica - u podsvest pisca, stiže do simbolizacije prostora i razvoja psihološko filozofskih tema. Uz kamen kuće, orjentaciju ka i nasuprot moru, svetlost i senku Desnica će eksplicitno uključiti i Sunce, njegovu toplinu, boje i nasuprot njemu tamu, svet bez svetlosti, gluvost mračnih soba.

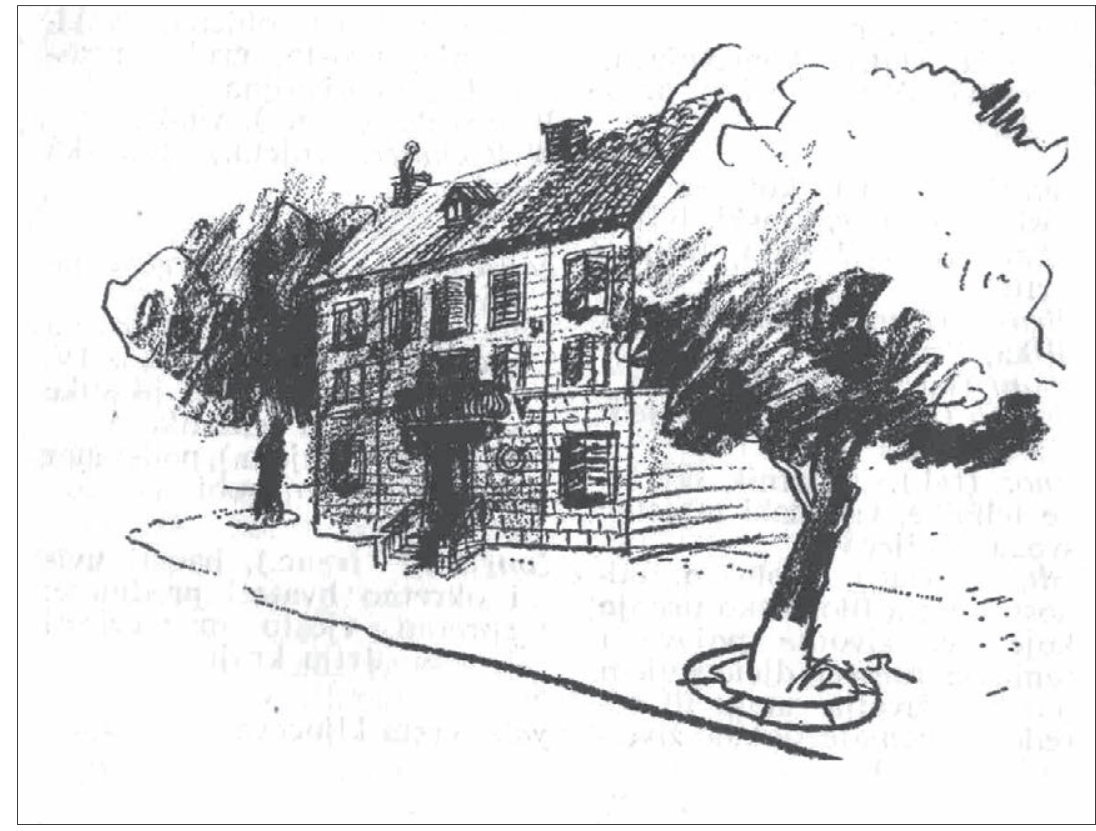

Sl. 1. Ilustracija Ratka Janjića u Proljećima Ivana Galeba (Pet stoljeća hrvatske književnosti, Matica Hrvatska i Zora, Zagreb 1977.) 
Stapajući osnovne praelemente bivstva sveta - kamen, more i sunce - Desnica ulazi u samu srž umetničkih tema i ambivalentnosti ljudskog postojanja; naši životi su neka vrsta hodnika Galebove kuće detinjstva u kojoj se sudaraju svetlo i tama i ceo naš vek se kreće od tačke rođenja do tačke smrti. Zbog toga je Desnici esencijalni dalmatinski pejzaž i simbolizacija urbanog prostora bila osnova ličnog života, ali i izvor najvećih tema književnosti i filozofije. Ljubav, smrt i vreme su - reći će jedan od najvećih srpskih pesnika Ivan V. Lalić, koji je sazrevao i odrastao u okruženju Vladana Desnice u Zagrebu - tri glavna motiva umetničke književnosti. Sudari svetla i senki, života i nagoveštaja smrti su vanredno opisani već na prvim stranicama Proljeća Ivana Galeba:

I kad bi se s prozora koji su gledali na more prešlo na prozore sjenovite strane, prelaz je bio tako nagao a promjena slike i raspoloženja tako velika kao da prelaziš iz jednog svijeta u drugi. Dugački hodnik bio je razmeđe dvaju carstava: tu su se ukrštavali svjetlost i sjena. $\mathrm{Na}$ svim vratima bila su debela mliječna stakla; ona na desnoj, sunčanoj strani sjala su u žaru, oživljena žutilom sunca koje je nadiralo i čisto previralo preko okvira, a u brušenim rubovima lomile su se zrake rasipljući se u jarkim duginim bojama; ona na lijevoj strani bila su nijema, zastrta neprozirnom opalskom zamagljenošću, i, predvečer, lagano podlivena plavkastim odsjevima. ${ }^{29}$

Čak i kugle „zasićene plav(e) boj(e)“ „,̌isto“ žive, a iz njih izvire ,jantarožutni svjetlac“ dok na senovitoj strani kugle ostaju zamućene i u njima je „ubijen živac“. Dakle, pred nama je nagoveštaj sveta bez živosti i topline mediteranskog sunca, $s$ jedne strane svjetlac, a sa druge „ubijeni živac“. U tom hodniku se razvila ta večita dvojnost, kako kaže Ivan Galeb, a mi bismo dodali ambivalentnost života na sferu svetla i mraka. Desničina dihotomija svetlosti i mraka, aktivizma i pasivnosti, lepog i ružnog je osnova koja polazi od tih diskretnih pejzažnih elemenata prelomljenih kroz prostor kuće, opet bazičnog mesta ljudskog bića, njegovog staništa koje biva susret dva sveta, sudar misaonog dejstva sveta dobra i sveta zla, filozofije sveta na sunčanoj i onog na senovitoj strani. Treba se setiti da će i Ivo Andrić u kasnijim pripovetkama objavljenim posle 1945. godine tragati za filozofijom mediteranske svetlosti u „Letovanju na jugu“ ili u pripoveci „Žena na kamenu“, igre svetlosti i sene biće vrhunski izvedene u "Jeleni ženi koje nema“ dok će i nedovršeni roman nositi naslov $\mathrm{Na}$ sunčanoj strani. Pored ove male paralele pisaca savremenika možemo videti da je i vraćanje elementarnostima sveta osnova Valerijevog „Groblja pored mora“ ili filozofske pripovetke Jovana Hristića „Terasa na dva mora“ koja će prizivati i kontekst Valerija, ali i Zenonovu filozofiju svetlosti i senki. ${ }^{30}$ Alber Kami u eseju Pobunjeni čovek 1951. godine u petom delu „Južnjačka misao" proslavlja sunce u zenitu i svetlost kao trenutak istine. Ta svetlost ima moralno filozofski smisao jer je to „neka granica na suncu“ koja zaustavlja pobunjenike, bezmerje i način da se zaustavi borba između „nemačke ideologije i sredozemnog duha“ $t j$. između nezasitih vladara i ljudske prirode čiju tajnu čuva Mediteran. Desničin junak će putujući po svetu pamtiti gradove i mesta po količini svetlosti i oblaka, a to je veoma blisko

29 V. Desnica, Proljeća Ivana Galeba, 9.

30 Videti: Jovan Hristić, Terasa na dva mora i druge istinite priče, Beograd 2002. Videti i naše tumačenje podneva na moru u Hristićevoj pripoveci: Svetlana ŠEatović Dimitrijević, „Mistika Hristićevog podneva“, Moderni klasicista Jovan Hristić. Zbornik radova (ur. Aleksandar Jovanović), Beograd 2009., 221-240. 
Kamijevom eseju gde se kaže: „Ta protivteža, taj duh koji odmerava život, to je upravo onaj duh koji oživljava dugu tradiciju onoga što se može nazvati sunčevom mišlju, a u kojoj je, još od Grka, priroda uvek bila ravnoteža sa postojanjem. “"31 Desničin Ivan Galeb kao antički junak polazi od količine svetlosti kao osnovnog, supstancijalnog merila smisla života i moralnog stava. Ta ideja je dalmatinska, ali je i mediteranska jer će Iv Bonfoa reći: „(...) sav Mediteran se ujedinjuje oko grčke ideje o očiglednosti, reči koja ima isto poreklo kao 'svetlost.'. 32 Zbog toga igre proljeća i smrti su te dihotomije dalmatinskog mediteranizma okupanog regionalnim osobinama, ali ujedinjenih širom mediteranskom filozofijom lepote i snage svetlosti, one koja stoji nasuprot hiperborejskih magli, one koja je dala najveće tehničke, filozofske i humanističke potencijale sveta, od prapočetaka do savremenog doba. Zbog toga su igre svetlosti i sene u splitskoj kući sa dugačkim hodnikom simboličke igre dobra i zla, sveta kome treba reći „da“ uprkos svim bezličnostima, reći „da“ životu u svoj njegovoj punoći kako nam je dat. Samo na Mediteranu, pa u i Desničinim splitskim danima život je mogao da ima svu punoću postojanja koja se prelila i duboko utkala u pripovetke, a najdublje u Ivana Galeba. Desničin junak Ivan Galeb eksplicitno i kaže:

Ja čak mislim da se u toj igri naizmjeničnosti i sastoji život, da ta izmjena obasjanostî i zasjenicâ i jeste arsa i teze našeg živoga daha, sistola i dijastola našega živoga srca. I kad bacim pogled unatrag na život, on mi se ukazuje kao ljeskava i nemirna površina satkana od krpica svjetlosti i od krpica mraka. ${ }^{33}$

Tako se dalmatinski ambijent najdublje utkiva u srž filozofije glavnog junaka koja i jeste jedna od osnovnih tema filozofije i književnosti, a to je „smrt u sunčanom podnevu“. Ivan Galeb će čak kazati:

Želio bih umrijeti u sunčanom danu (...) Želio bih umrijeti izvaljen nauznak na dobroj, vrućoj zemlji, sav u suncu i jásu, umrijeti u jedrini dana, u sat uzavrelih zrikavaca (...) Pitam se, uvijek nanovo, već po ne znam koji put, što je to što nas tako silno mami k svjetlosti, to čim nas tako silno odbija mrak? (...) Znam samo da je to oduvijek bila alfa i omega mog života. ${ }^{34}$

To je rečenica koja neodoljivo podseća na misao Gotfrida Bena i pesmu „Nikad sam kao kad“ u kojoj ovaj nemački pesnik kaže: „Umreti u letnjem sunčanom danu kad je zemlja pod ašovom laka." ${ }^{35}$ Pesnik Ivan V. Lalić će gotovo prorokovati svoju smrt u pesmi „Nikad samlji“ u kojoj će se prizivati smrt:

Nikad samlji nego krajem jula

Kad je letu pedalj do zenita,

A hlorofilu aršin do rasula

U metastazi žutila i ruja,

Tamnije kada zelene su boje

U vrtovima, a strnjika suva,

\footnotetext{
31 Alber Kami, Eseji, Beograd 2008., 447.

32 Yves Bonnefoy, „Moins une mer que des rives“, Les Poètes de la Méditerranée. Anthologie, Paris 2010., 12.

33 V. Desnica, Proljeća Ivana Galeba, 11.

34 Isto, 72.

35 Gotfrid Ben, „Nikad sam kao kad“, Izabrane pesme, Beograd 1984., 34.
} 


\section{Tamnija donja amplituda bruja}

Vetar što obnoć u vremenu duva ${ }^{36}$

Lalića će smrt i zadesiti krajem jula kao neka vrsta životne anticipacije koja se ponavljala u njegovom pesničkom opusu kao antički literarni motiv. Ivan Galeb će poslednje spoznanje sunca i sreće naći „u proletnjem danu, kori ljeba, krpi neba sa šakom zvijezda nad glavom“ i napokon: „U meni tišina, nada mnom podne bez ruba, uokolo prizori zemlje u dobroj poplavi sunca. ${ }^{\text {"37 }}$ Poetika podneva kao najvišeg oblika saznanja i epifanijskog susreta sa Apsolutom, ali i totalnog spoznanja sveta česta je među piscima Mediterana, a u posleratnom periodu Vladimir Nazor će u pesmi „Podne“ opevati mediteranski ambijent zrikavaca i savršenog mira, dok će Ivan V. Lalić u pesmi „Plava grobnica“ u podne spoznati istorijske nacionalne zablude iz Prvog svetskog rata i istine na ostrvu Krfu sedamdeset godina posle Albanske golgote. U prvom delu rada već smo navodili primere Dučićevog podneva i nadrealističkih epifanijskih doživljaja istine u trenutku podnevnog Apsoluta. Time je podne trenutak najvišeg saznanja i čas idealne smrti pesničkog bića. Podne na moru u Nazorovoj i Lalićevoj pesmi, kao i u Desničinom romanu su istovetni doživljaji epifanije i istine u punom Sunčevom sjaju. Vladan Desnica je u intrevjuu sa Jevtom Milovićem sunčane dane pune svetlosti obeležio i kao dane pune kreativne energije:

Mogu reći uglavnom en général da radim samo po sunčanom vremenu. Kad su mutljavine, magle, kiše, i tako dalje, tad nešto popravljam, dotjerujem - onaj tehnički rad, ali stvaralački rad samo po lijepom i sunčanom danu. ${ }^{38}$

Desnica će kasnije dodati da su njegovi najkreativniji periodi u godini proleće i leto, juni, juli, pa je tek sredinom avgusta odlazio na odmor. U ličnom razgovoru sa Olgom Škarić, ćerkom Vladana Desnice u septembru 2014. godine saznali smo da je upravo svetlost bila osnovni pokretač, suština idealnog stanja Vladana Desnice. Tako se pred nama iz filozofskih, estetskih stavova o sunčanoj strani sveta, poetičkih osobenosti junaka i atmosfere i na kraju autobiografskih iskaza i svedočenja nalazimo u svetlosti kao izvoru kreativne, pozitivne energije toliko autentične za prostore Dalmacije i Mediterana. Napokon i smrt je idealna u sunčanom danu!

Pored ovih glavnih elemenata filozofije i sveta na koje je indirektno sveo svet Vladan Desnica u Proljeću Ivana Galeba pred nama će se otvarati ceo spektar mediteranskih i dalmatinskih običaja, jezika, poslova, štimunga. Tako je pred čitaocima deda, vlasnik pomorske agencije, tu je i česta mediteranska tema smrti oca pomorca, a potom mistika građanskih tavana, vrela letnja popodneva, zrela nedelja, vreme sijeste, zvuk zvona sa fratarskog manastira u suton, popodnevna kupanja u moru, uske kamene ulice ribarskog predgrađa, mornarske udovice, „ribarske nevjenčane žene“ što sede na pragovima predući vunu ili do-

\footnotetext{
36 Dela Ivana V. Lalića, sv. 3 (prir. Aleksandar Jovanović), Beograd 1997., 165. U istom izdanju posle pesme „Nikad samlji“ nalazi se i pesma „Ravnodnevica“ koja tematizuje podne i njegovu metafiziku: „(..) Sve je u znaku polovine puta/Sinkopa koju senkom slutnje prati/Figura non ancora conosciuta -/Dvojnik tog dana što se tromo zlati." Isto, 166.

37 V. Desnica, Proljeća Ivana Galeba, 345.

38 J. M. Milović, „Razgovor s Vladanom Desnicom o umjetničkom stvaranju“, 234.
} 
jeći decu kao specifični socijalni oblici primorskih gradova i netipičnih bračnih zajednica, melanholija i nostalgija naselja uz more. To su kao ugravirane slike splitskih ulica, sudbina i običaja sveta što živi uz more i od mora sa svim blagodetima i nesrećama koje donosi ta plava pučina. Napokon i smrt Galebovog oca je bila na pučini, a njegovo telo je predato moru. Junak će se ceo život sećati priča po gradu o kožnoj vreći u koju je smešten njegov otac i sahranjen do legendi o očevom tajnom životu negde u Južnoj Americi sa drugom porodicom. Time smrt oca na moru postaje jedna vrsta fantazmagoričnog doživljaja u kome je teško razdvojiti istinu, gradske legende i prepričavanja tipična za male mediteranske ulice i frustraciju Ivana Galeba koji nikada nije upoznao oca, a opet nije bio ni siguran u njegovu smrt. Smrt mladog bića u moru, odnos života i smrti, pa i surovost te poluistine neki su od glavnih problema u konstituisanju identiteta Desničinog junaka. I to je jedna od čestih sudbina ljudi Dalmacije i Mediterana. Valeri daje objašnjenje te tajanstvene veze mora i života:

More je tajanstveno povezano sa životom (...) Postoji u njemu hijerarhija proždrljivaca; i uspostavljena statistička ravnoteža između vrsta koje jedu i vrsta koje su jedene. Smrt se pokazuje, dakle, kao suštinski uslov života, a ne neka vrsta nesrećnog slučaja koji nam svaki put izgleda kao kakvo stravično čudo; ona je zbog života, a ne protiv njega. Zivot, da bi živeo, mora da se obrati sam sebi, da udahne i izdahne toliko i toliko bića na dan, i mora da postoji prilično stalna proporcija među brojevima. Život ne voli preživljavanje (... $)^{39}$

Tako je u životu Ivana Galeba smrt oca na moru bila i zalog novog enigmatičnog života, ali to more je ujedno bilo i izvor života i neophodnih finansija cele porodice. Tako su smrt i život, pa i očeva smrt koja je potekla iz potrebe za ostvarenjem egzistencije, nerazdvojivi pojmovi u širem sklopu ljudi mediteranskih podneblja. Dušan Matić 1961. godine objavljuje esej „Grčka ili iskustvo smrti“, gde će ovaj nadrealistički pisac spoznati da je svetlost na Atici „sama stvarnost“, a potom će se setiti jednog letovanja u Hvaru na Hvaru: „U Hvaru, na Hvaru, oko jedan sat po podne, samo belosivi kamen kuća, tamni zatvoreni kapci prozora, ono nekoliko borova na brežuljku gde je groblje, tišina i svetlost legli na kamen i vodu. Sad znam to je bila ta svetlost. "“0 To more i svetlost i na Hvaru naspram Splita su bili vrhunska ideja spoznanja sveta i stvarnosti života za Dušana Matića. ${ }^{41}$ Uz još jednu književnoistorijsku paralelu vidimo da su pisci savremenici vrlo često bili na sličnom tragu smisla svetlosti, mora, kamena i Sredozemlja. More koje daje i more koje uzima i to je ambivalentnost Desničinog romana, pesama i eseja, ali i dihotomija sveta dalmatinskog $\mathrm{i}$ mediteranskog duha na splitskoj obali i u zaleđu rodnog Islama Grčkog.

39 Pol VAleri, Mediteranska nadahnuća: ogledi i pogledi, Velereč 2011., 548.

40 Dušan Matić, Izbor tekstova, Novi Sad - Beograd 1966., 311. Detaljnije tumačenje Matićevog, Lalićevog i Hristićevog podneva i svetlosti na moru videti u našem tekstu: Svetlana Šeatović Dimitrijević, „Pesnici svetlosti i mora“, Acqua alta. Međunarodni zbornik radova. Mediteranski pejzaži u modernoj srpskoj i italijanskoj književnosti (ur. Svetlana Šeatović Dimitrijević, Marija Rita Leto i Persida Lazarević Di Đakomo), Beograd 2013., 455-485.

41 Vlatko Pavletić o Dušanu Matiću i njegovim nadrealističkim vizijama piše: „Srpski pjesnik Dušan Matić (...) izrazio [je] svoje uvjerenje da je poezija autentična samo onda kad je otkrivačka, a ne proizvođačka, dakle, kada stihovi ožive i bujaju od jedinstvenih, neponovljivih otkrivenja, jer da su (nepobitno!?) sve pjesničke istine samo bljesak munje!“” V. PAvletić, Trenutak vječnosti, 106. 


\section{$\cos$}

\section{The Dalmatian Mediterraneanism of Vladan Desnica: The Split Period}

This paper looks into the relations between the Dalmatian and regional space in which Vladan Desnica grew and matured. Special thought has been given to the period of his life he spent in Split, when he wrote several short stories and a part of the novel Proljeća Ivana Galeba. The relationship between poetic, philosophical and historical, sociological and anthropological characteristics connected to life in Split and the mentioned prose works from this phase of Desnica's life was analyzed through the texts of Vladimir Rismondo, who distinguished the Mediterranean, regional or ancient thought of the Mediterranean basin. In interpreting Desnica's Split period we have analyzed several poems written in Split and published in the journal Magazin Sjeverne Dalmacije, edited by Vladan Desnica in 1934 and 1935. We also took account of two essays, on Dositej and Korolija, published in the Magazin Sjeverne Dalmacije. Proljeća Ivana Galeba is a novel Desnica began to write in Split. There he also wrote the largest part dedicated to the childhood of Ivan Galeb. In this way we established connections between life in Split and the literary texts which carry notable markings of this city or memories of Islam Grčki. Desnica's complete opus has the features of Mediterraneanism, interpreted here through the ideas of Ferdinand Braudel, the role of space, history, civilization in the formation of men and their art. Dalmatian Mediterraneanism is only a landscape which is a discrete framing device in Desnica's work, but this trait is an initial impulse that brings forward Italian literary influences, Croce's aesthetic and translations of Leopardi and D'Annunzio. Vladan Desnica's opus from the Split period is viewed as a cultural form of Mediterraneanism in the corpus of Serbian and Croatian literature, but also of wider regional and culturological communities of Mediterranean people to which this writer belonged by birth and education. Proljeća Ivana Galeba puts into conflict two basic themes of life and death, such as is metaforically implied in the games of spring and death in an authentic Mediterranean ambient, comparativelly inviting a whole array of Mediterranean writers; Albert Camus, Yves Bonnefoy, Pa$\mathrm{ul}$ Valery and his ideas in book Mediterranean Inspirations. Although there is significant difference between Desnica and Valery in view of their chosen genres, the common trait is the thought of life and death based on ancient philosophies. Numerous commonalities connected to Dalmatian Mediterraneanism and the metaphysic of light, Sun, noon and epiphany are corroborated with examples from the poetry of Jovan Dučić, Vladimir Nazor, Dušan Matić, Ivan V. Lalić and Jovan Hristić.

Keywords: Mediterranean, Dalmatia, anthropogeography, landscape, biography, imagination, sea, Sun

\section{$\cos$}

\section{Literatura}

Gotfrid Ben, Izabrane pesme, Beograd 1984.

Yves Bonnefoy, „Moins une mer que des rives“, Les Poètes de la Méditerranée. Anthologie, Paris 2010., 3-15.

Fernan Brodel, Mediteran i mediteranski svet u doba Filipa II, sv. 2, Beograd 2001. 
Jovan Cvijıć, Psibičke osobine Južnih Slovena, Beograd 2006.

Dela Ivana V. Lalića (prir. Aleksandar Jovanović), sv. 3, Beograd 1997.

Vladan Desnica, „Ljetni motiv“, Magazin Sjeverne Dalmacije, 1/1934., 89.

Vladan Desnica, „Mirko Korolija i njegov kraj“, Magazin Sjeverne Dalmacije, 2/1935., 117-129.

Vladan Desnica, „O jednom gradu i jednoj knjizi“, Eseji, kritike, pogledi (= Sabrana djela Vladana Desnice, knj. IV), Zagreb 1975., 92-104.

Vladan Desnica, Proljeća Ivana Galeba, Zagreb 1982.

Vladan Desnica, Slijepac na žalu, Zagreb 1956.

Jovan Dučić, Pesme (= Dela Jovana Dučića, sv. 1, prir. Rajko Petrov Nogo), Beograd - Podgorica - Trebinje 2000.

Željko Đurić, „Vladan Desnica i italijanska književnost“, Književno delo Vladana Desnice (ur. Jovan Radulović i Dušan Ivanić), Beograd 2007., 162-174.

Jovan Hristić, Terasa na dva mora i druge istinite priče, Beograd 2002.

Ljubo Jandrić, Sa Ivom Andrićem, Beograd 1977.

Alber Kami, Eseji, Beograd 2008.

Dušan Matić, Izbor tekstova, Novi Sad - Beograd 1966.

Jevto M. Milović, „Razgovor s Vladanom Desnicom o umjetničkom stvaranju“, u: Vladan DesniCA, Eseji, kritike, pogledi (= Sabrana djela Vladana Desnice, knj. IV), Zagreb 1975., 214-245.

Vlatko Pavletić, Trenutak vječnosti. Uvođenje u poetiku epifanija, Zagreb 2008.

Vladimir Rismondo, „Književni profil Vladana Desnice“, Oblici i slova, Split 1979., 179-183.

Vladimir Rismondo, „Poezija Vladana Desnice“, Oblici i slova, Split 1979., 133-136.

Vladimir Rismondo, „Sjećanja na Vladana Desnicu“, Oblici i slova, Split 1979., 210-220.

Drago Roksandić, „Ratni dani Vladana Desnice“, Intelektualci i rat 1939. - 1947. Zbornik radova s međunarodnog skupa Desničini susretia 2012. (ur. Drago Roksandić i Ivana Cvijović Javorina), sv. 2, Zagreb 2013., 529-553.

Svetlana ŠEatović Dimitrijević, „Mistika Hristićevog podneva“, Moderni klasicista Jovan Hristić. Zbornik radova (ur. Aleksandar Jovanović), Beograd 2009., 221-240.

Svetlana Šeatović Dimitrijević, „Pesnici svetlosti i mora“, Acqua alta. Mecunarodni zbornik radova. Mediteranski pejzaži u modernoj srpskoj i italijanskoj književnosti (ur. Svetlana Šeatović Dimitrijević, Marija Rita Leto i Persida Lazarević Di Đakomo), Beograd 2013., 455-485.

Pol Valeri, Mediteranska nadahnuća: ogledi i pogledi, Velereč 2011. 